P ISSN : 2503 - 1708

E ISSN : 2722 - 7340

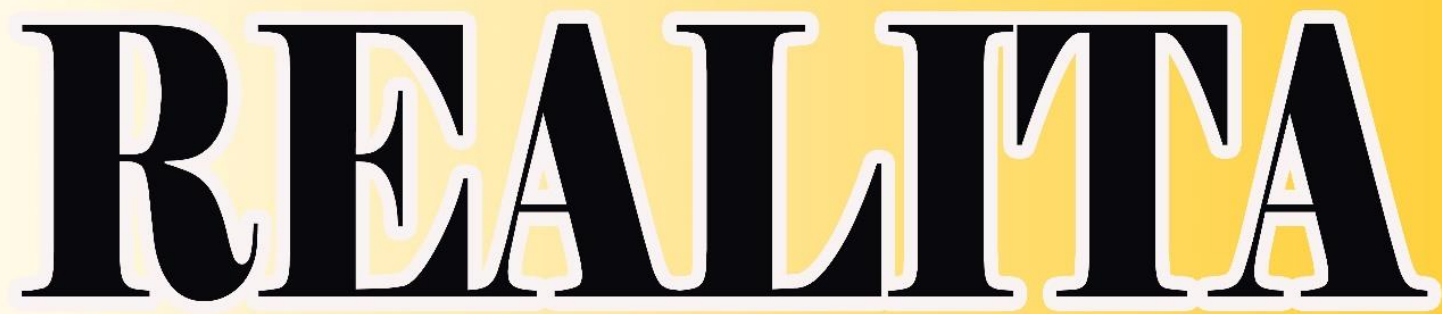

Jurnal Bimbingan dan Konseling

\begin{tabular}{|c|c|c|c|c|c|}
\hline JURNAL & VOLUME & NOMOR & EDISI & HALAMAN & P ISSN : 2503 - 1708 \\
REALITA & 6 & 2 & Oktober 2021 & $1326-1430$ & E ISSN : 2722 - 7340 \\
\hline
\end{tabular}

Diterbitkan oleh:

PROGRAM STUDI BIMBINGAN DAN KONSELING FAKULTAS ILMU PENDIDIKAN DAN PSIKOLOGI UNIVERSITAS PENDIDIKAN MANDALIKA 


\section{REALITA \\ BIMBINGAN DAN KONSELING \\ Jurnal Penelitian dan Pengembangan Pendidikan}

\section{DEWAN REDAKASI \\ Pelindung : Rektor Universitas Pendidikan Mandalika \\ : Dekan FIPP Universitas Pendidikan Mandalika \\ Penanggung \\ Jawab \\ : Kaprodi BK FIPP Universitas Pendidikan Mandalika \\ Editor}

Hariadi Ahmad, M.Pd

Universitas Pendidikan Mandalika

Associate Editor

Mustakim, M.Pd

Universitas Pendidikan Mandalika

Mujiburrahman, M.Pd

Universitas Pendidikan Mandalika

Ahmad Muzanni, M.Pd

Universitas Pendidikan Mandalika

M. Chaerul Anam, M.Pd

Universitas Pendidikan Mandalika

\section{Editorial Board}

Prof. Drs. Kusno, DEA., Ph.D

Universitas Negeri Jember Jawa Timur

Drs. Wayan Tamba, M.Pd

Farida Herna Astuti, M.Pd

Ichwanul Mustakim, M.Pd

Reza Zulaifi, M.Pd

Jessica Festi Maharani, M.Pd

Universitas Pendidikan Mandalika

Universitas Pendidikan Mandalika

Universitas Pendidikan Mandalika

Universitas Pendidikan Mandalika

Universitas Pendidikan Mandalika

\section{Reviwer}

Dr. I Made Sonny Gunawan, S.Pd., M.Pd

Universitas Pendidikan Mandalika

Dr. A. Hari Witono, M.Pd

Universitas Mataram NTB

Prof. Dr. Wayan Maba

Universitas Mahasaraswati Bali

Dr. Gunawan, M.Pd

Universitas Mataram NTB

Dr. Haromain, S.Pd., M.Pd.

Universitas Pendidikan Mandalika

Dr. Hadi Gunawan Sakti, M.Pd

Wiryo Nuryono, M.Pd

Hasrul, S.PdI., M.Pd

Dita Kurnia Sari, M.Pd

Dr. Roro Umy Badriyah. M.Pd., Kons

Universitas Pendidikan Mandalika

Universitas Negeri Surabaya Jawa Timur

STKIP Kie Raha Ternate Maluku Utara

UIN Sunan Ampel Surabaya Jawa Timur

Universitas PGRI Maha Dewa Bali

Ari Khusumadewi, M.Pd

Universitas Negeri Surabaya Jawa Timur 
M. Najamuddin, M.Pd

M. Samsul Hadi, M.Pd

Lalu Jaswandi, M.Pd

Eneng Garnika, M.Pd

Aluh Hartati, M.Pd

Drs. I Made Gunawan, M.Pd

Nuraeni, S.Pd., M.Si

Baiq Sarlita Kartiani, M.Pd

M. Zainuddin, M.Pd

Ahmad Zainul Irfan, M.Pd

Dra. Ni Ketut Alit Suarti, M.Pd

Asep Sahrudin, S.Pd., M.Pd

Suciati Rahayu Widyastuti, S.Pd., M.Pd

Rahmawati M, S.Pd., M.Pd

Ginanjar Nugraheningsih, S.Pd. Jas., M.Or

Dewi Ariani, S.Pd., M.Pd

St. Muriati, S.Pd., M.Pd

Uli Agustina Gultom, S.Pd., M.Pd

Indra Zultiar, S.Pd., M.Pd.
Universitas Pendidikan Mandalika

Universitas Pendidikan Mandalika

Universitas Pendidikan Mandalika

Universitas Pendidikan Mandalika

Universitas Pendidikan Mandalika

Universitas Pendidikan Mandalika

Universitas Pendidikan Mandalika

Universitas Pendidikan Mandalika

Universitas Pendidikan Mandalika

Universitas Pendidikan Mandalika

Universitas Pendidikan Mandalika

Univ. Mathla'ul Anwar Banten

Univ. Nahdlatul Ulama Cirebon

Universitas Muhammadiyah Kendari Sulawesi Tenggara

Universitas Mercu Buana Yogyakarta

Universitas Mahaputra Muhammad Yamin Solok Sumatera Barat

Universitas Bosowa Makassar Sulawesi Selatan

Universitas Borneo Tarakan Kalimantan Utara

Universitas Muhammadiyah Sukabumi Jawa Barat

\section{Alamat Redaksi:}

Redaksi Jurnal Realita Bimbingan dan Konseling (JRbk)

Program Studi Bimbingan dan Konseling

Fakultas Ilmu Pendidikan dan Psikologi Universitas Pendidikan Mandalika

Gedung Dwitiya, Lt. 3 Jalan Pemuda No. 59 A Mataram Telp. (0370) 638991

Email : realita@undikma.ac.id

Web : e-journal.undikma.ac.id

Jurnal Realita Bimbingan dan Konseling menerima naskah tulisan penulis yang original (belum pernah diterbitkan sebelumnya) dalam bentuk soft file, office word document (Email) atau Submission lansung di akun yang diterbitkan setiap bulan April dan Oktober setiap tahun.

Diterbitkan Oleh: Program Studi Bimbingan dan Konseling Fakultas Ilmu Pendidikan dan Psikologi Universitas Pendidikan Mandalika. 


\section{DAFTAR ISI}

Halaman

\section{Nuraeni dan Mastari}

Pengaruh Konseling Kelompok Terhadap Self Esteem Siswa Kelas XI di SMK Negeri 2 Kuripan

\section{Aprilia Yolanda, Ni Ketut Alit Suarti dan Ahmad Muzanni}

Pengaruh Body Shaming Terhadap Kepercayaan Diri Siswa SMA Negeri

1 Batulayar

$1342-1353$

\section{Hariadi Ahmad}

Hubungan Kestabilan Emosi dengan Kontrol Diri Siswa Sekolah Menegah Pertama

\section{Aluh Hartati}

Pengaruh Teknik Modeling Untuk Meningkatkan Empati Siswa

\section{Mustakim}

Pengaruh Teknik Cerita Terhadap Sikap Kemandirian Anak Pada Usia 5-6 Tahun

\section{Farida Herna Astuti dan Ichwanul Mustakim}

Keefektifan Bimbingan Kelompok dengan Teknik Role Playing untuk Meningkatkan Motivasi Belajar

\section{Mujiburrahman dan Soba Al-Qadri}

Hubungan Antara Kemampuan Kontrol Diri Dengan Penyusaian Diri Pada Siswa Kelas XI SMA Negeri 1 Taliwang

\section{Wiwiek Zainar Sri Utami}

Pengaruh Konseling Individu Terhadap Potensi Diri Anak Tunarungu di Sekolah Inklusi

\section{Baiq Nur'aini Cahya Khairani dan Ni Made Sulastri}

Pengaruh Layanan Konseling Humanistik Terhadap Perilaku Agresif pada Siswa Kelas XI IPS-4 di SMA Negeri 7 Mataram

\section{Najamudin}

Pengaruh Teknik Biblioterapi Terhadap Sikap Kemandirian Belajar Pada Siswa VIII SMP Negeri 5 Lembar

\section{Khaerul Huda}

Meningkatkan Pengetahuan dan Pemahaman Perilaku Hidup Bersih dan Sehat dimasa Covid 19 Melalui Metode Demontrasi pada Kelompok B di TK Negeri 01 Wanasaba 


\title{
PENGARUH KONSELING INDIVIDU TERHADAP POTENSI DIRI ANAK TUNARUNGU DI SEKOLAH INKLUSI
}

\author{
Oleh: \\ Wiwiek Zainar Sri Utami \\ Dosen Program Studi Bimbingan dan Konseling Fakultas Ilmu Pendidikan dan \\ Psikologi Universitas Pendidikan Mandalika Mataram Nusa Tenggara Barat Indonesia \\ Email: wiwiekutami@ikipmataram.ac.id
}

\begin{abstract}
Abstrak. Konseling individu merupakan salah satu pemberian bantuan psikis secara perseorangan. Sasarannya pada siswa tunarungu yang memiliki keterbatasan serta mengakibatkan penurunan prestasi. Pengaruh konseling dan peningkatan perlakuan konseling pada siswa tunarungu dapat meningkatkan potensi diri. Peneliti menemukan adanya pengaruh dari kasus dan permasalahan yang di alami dari siswa tunarungu pada kelas $\mathrm{X}$ dan $\mathrm{Xl}$ di sekolah inklusi SMKN 5 Mataram. Tujuan penelitian ini yaitu mengetahui apakah ada pengaruh konseling individu terhadap potensi diri anak tunarungu disekolah SMKN 5 Mataram. Penggunaa metode ini adalah metode kualitatif dengan Pre-experiental design (nondesign) atau eksperimen tidak murni, desain eksperimen One group Pretest-Posttest design, cara pengambilan sampel dengan teknik porpusive sampling dan di temukan 30 siswa, kemudian di tetapkan 7 siswa menggunakan hasil pre-test, setelahnya dilakukan treatment, pengumpulan data dengan metode angket, wawancara, dan observasi. Teknik analisis data menggunakan tabel t-test. Berdasarkan hasil analisis data penelitian yaitu: ( $\mathrm{t}$ hitung4.321 > t tabel2.447)
\end{abstract}

Kata Kunci: Konseling Individu, Potensi diri, dan Tunarungu

\section{PENDAHULUAN}

Pendengaran adalah anugerah dari Tuhan yang Maha Esa dan sekaligus merupakan salah satu modal hidup bagi manusia karena dengan pendengaran inilah manusia akan mendapatkan berbagai hal, diantaranya dua hal penting yaitu berbahasa dan berkomunikasi. Anak tunarungu adalah anak yang mengalami kehilangan fungsi pendengaran, baik sebagian maupun seluruhnya yang berdampak kompleks dalam kehidupannya. Anak tunarungu secara fisik terlihat seperti anak normal, tetapi bila diajak berkomunikasi barulah terlihat bahwa anak mengalami gangguan pendengaran. Anak tunarungu tidak berarti anak itu tunawicara, akan tetapi pada umumnya anak tunarungu mengalami ketunaan sekunder yaitu tunawicara. Penyebabnya adalah anak sangat sedikit memiliki kosakata dalam sistem otak dan anak tidak terbiasa berbicara. (H. Bonner dalam Abu Ahmadi, 2007).
Anak tunarungu memiliki karakteristik tertentu dalam aspek akademik, sosial-emosional, dan fisik. Anak tunarungu mengalami keterbatasan dalam kemampuan berbicara dan berbahasa, yang mengakibatkan anak tunarungu cenderung memiliki prestasi yang rendah dalam mata pelajaran yang bersifat verbal dan cenderung sama dalam mata pelajaran yang bersifat nonverbal dengan anak normal seusianya. Pergaulan anak tunarungu dalam aspek sosial-emosional yaitu terbatas dengan sesama tunarungu, sebagai akibat dari keterbatasan dalam kemampuan berkomunikasi. Sifat egosentris dan sikap sensitive anak tunarungu melebihi anak normal, ditunjukkan dengan sukarnya mereka menempatkan diri pada situasi berfikir dan perasaan orang lain; sukar atau sulit menyesuaikan diri; serta tindakannya lebih terpusat pada "aku/ego", sehingga kalau ada keinginan harus selalu dipenuhi. Anak tunarungu memiliki 
perasaan takut (khawatir) terhadap lingkungan sekitar, sehingga mereka tergantung pada orang lain serta kurang percaya diri. Oleh karena itu anak tunarungu membutuhkan memerlukan layanan atau bantuan secara khusus yang disesuaikan dengan karakteristik, kemampuan, dan ketidakmampuannya seperti semua anak tanpa terkecuali untuk mengembangkan potensinya secara optimal dan mengurangi sikap sensitif yang diakibatkan oleh sikap rendah diri dan merasa berbeda dari teman-temannya dikelas inklusi. (Mohammad Efendi, 2006)

Selama beberapa dekade yang lalu, pendidikan di Indonesia telah mengalami banyak perubahan dalam sistem pendidikan bagi anak penyandang disabilitas. Sistem pendidikan tersebut adalah pendidikan segregasi, integrasi, maupun inklusi. Perubahan-perubahan ini termasuk perubahan dalam kesadaran dan sikap, keadaan, metodologi, penggunaan konsep-konsep terkait dan sebagainya. Perubahan-perubahan ini tidak hanya relevan bagi kepentingan dan pengayaan anak penyandang cacat, tetapi juga bagi pengayaan semua yang terlibat; anakanak (dengan atau tanpa kecacatan), keluarganya, guru-guru dan kepala sekolahnya, komunitas sekolahnya dan mungkin masyarakat secara keseluruhan. Konsekuensi yang paling penting dari perubahan-perubahan ini adalah pengakuan dan penghargaan akan adanya keragaman. Hal ini juga menghasilkan upaya-upaya untuk "membawa kembali" ke dalam masyarakat mereka yang sebelumnya telah dipisahkan atau disegregasikan oleh mayoritas terbesar masyarakat karena mereka berbeda. (Mudjito, 2012)

Pendidikan inklusif merupakan suatu pendekatan pendidikan yang inovatif dan strategis untuk memperluas akses pendidikan bagi semua anak berkebutuhan khusus termasuk anak tunarungu. Dalam konteks yang lebih luas, pendidikan inklusi juga dapat dimaknai sebagi satu bentuk reformasi pendidikan yang menekankan sikap anti diskriminasi, perjuangan persamaan hak dan kesempatan, keadilan, dan perluasan akses pendidikan bagi semua, peningkatan mutu pendidikan, upaya strategis dalam menuntaskan wajib belajar 9 tahun, serta upaya merubah sikap masyarakat terhadap anak berkebutuhan khusus

Sekolah inklusi merupakan terobosan pemerintah dalam 5 tahun terakhir ini, untuk memberikan pelayanan khusus bagi anak berkebutuhan khusus di sekolah reguler agar dapat berkembang secara optimal, namun pada kenyataannya masih banyak masalah yang muncul baik dari segi kultural, kebijakan, maupun teknis itu sendiri. Hasil observasi kelas serta wawancara dengan kepala sekolah dan guru bimbingan konseling 5-6 September 2021 menunjukkan bahwa saat ini SMKN 5 Mataram memiliki 20 siswa yang merupakan anak tunarungu. salah satu permasalahn yang dihadapi anak tunarungu di SMKN 5 Mataram adalah anak mengalami tekanan yang membuat mereka kehilangan rasa percaya diri dan tidak memahami potensi diri yang ada dalam diri mereka. Hal tersebut membuat anak tunarungu menjauhkan diri dari lingkungan orang normal.

Sebuah penelitian dilakukan oleh Yanuar Umi Solikhatun (2013) tentang penyesuaian sosial pada siswa tunarungu di SLB Negeri Semarang. Hasil penelitian menunjukkan bahwa interaksi sosial yang dilakukan siswa tunarungu menggambarkan dalam dirinya cenderung memiliki rasa kurang percaya diri, minder, tidak mudah dekat dengan orang lain khususnya orang normal, kecenderungan bergaul dengan komunitasnya yaitu tunarungu, tingkat emosional yang tidak stabil dan pola 
komunikasi yang sulit dimengerti oleh lingkungan. Hal-hal tersebut membuat siswa tunarungu terhambat dalam penyesuaian sosialnya dan kurang memahami potensi diri yang mereka miliki. Oleh karena itu anak tunarungu membutuhkan layanan atau bantuan untuk mengembangkan potensinya secara optimal dan mengurangi sikap sensitif yang diakibatkan oleh sikap rendah diri dan merasa berbeda dari teman-temannya disekolah inklusi.

Setiap manusia memiliki bermacam-macam potensi diri yang dapat dikembangkan. Tidak sedikit manusia belum sepenuhnya mengembangkan dan menggunakan potensi yang ada pada dirinya. Hal ini terjadi dikarenakan mereka belum atau bahkan tidak mengenal potensi dirinya dan hambatan-hambatan dalam pengembangan potensi diri tersebut. Mampu mengembangkan potensi diri merupakan dambaan setiap individu. Mampukan seseorang mengembangkan potensi dirinya secara efektif Itu bergantung pada motivasi diri, karena pengembangan potensi diri merupakan suatu proses yang sistematis dan bertahap.

Menurut Undang-Undang Nomor 20 Tahun 2003 tentang sistem pendidikan nasional, pendidikan adalah usaha sadar dan terencana untuk mewujudkan suasana belajar dan proses pembelajaran agar peserta didik secara aktif mengembangkan potensi dirinya untuk memiliki kekuatan spiritual keagamaan, pengendalian diri, kepribadian kecerdasan akhlaq mulia, dan keterampilan yang dibutuhkan. Dengan demikian, tugas seorang guru bukanlah memberikan sebanyakbanyaknya ilmu pengetahuan kepada anak didiknya, melainkan membimbing mereka untuk tumbuh dan berkembang.

Konseling individu yaitu merupakan salah satu pemberian bantuan secara perseorangan dan secara langsung. Dalam cara ini pemberian bantuan dilakukan secara face to face relationship (hubungan muka ke muka, atau hubungan empat mata) antara konselor dengan individu yang terjadi ketika seorang konselor bertemu secara pribadi dengan seorang siswa untuk tujuan konseling. (Sofyan S. Willis, 2014). Tujuan konseling individu adalah membantu klien menstrukturkan kembali masalahnya dan menyadari lifestyle serta mengurangi penilaian negatif terhadap dirinya sendiri serta perasaan-perasaan inferioritasnya. Kemudian membantu dalam mengoreksi presepsinya terhadap lingkungan, agar klien bisa mengarahkan tingkah laku serta mengembangkan kembali minat sosialnya (Prayitno. 2005). Tujuan penelitian ini adalah Untuk Mengetahui Apakah Ada Pengaruh Konseling Individu Terhadap Potensi Diri Anak Tunarungu Di Sekolah Inklusi.

\section{KAJIAN PUSTAKA}

Konseling individu merupakan salah satu cara pemberian bantuan secara perseorangan dan secara langsung. Pemberian bantuan dilaksanakan secara face to face relationship (hubungan langsung muka ke muka, atau hubungan empat mata), antara konselor dan anak (kasus). Biasanya, masalah-masalah yang dipecahkan melalui teknik atau cara ini ialah masalah-masalah yang sifatnya pribadi.

Mortense mendefinisikan konseling sebagai suatu proses antar pribadi, di mana satu orang yang satu dibantu oleh yang lainnya untuk meningkatkan pemahaman dan kecakapan menemukan masalahnya. Selanjutnya Jones Menyebutkan bahwa konseling sebagai suatu hubungan professional antara seorang konselor yang terlatih dengan klien. Hubungan ini bersifat individual atau seorang-seorang. 
Konseling individu adalah proses belajar melalui hubungan khusus secara pribadi dalam wawancara antara seorang konselor dan seorang konseli/klien. Konseli/klien mengalami kesukaran pribadi yang tidak dapat dipecahkan sendiri, kemudian ia meminta bantuan konselor sebagai petugas yang profesional dalam jabatannya dengan pengetahuan dan ketrampilan psikologi. Konseling ditujukan pada individu yang normal, yang menghadapi kesukaran dalam mengalami masalah pendidikan, pekerjaan dan sosial di mana ia tidak dapat memilih dan memutuskan sendiri. Dapat disimpulkan bahwa konseling hanya ditujukan pada individu-individu yang sudah menyadari kehidupan pribadinya.

Tujuan konseling individu adalah agar klien memahami kondisi dirinya sendiri, lingkungannya, permasalahan yang dialami, kekuatan dan kelemahan dirinya sehingga klien mampu mengatasinya. Dengan perkataan lain, konseling individu bertujuan untuk mengentaskan masalah yang dialami klien Secara lebih khusus, tujuan layanan konseling individu adalah merujuk kepada fungsi-fungsi bimbingan dan konseling sebagaimana telah dikemukakan di muka. Pertama, merujuk kepada fungsi pemahaman, maka tujuan layanan konseling adalah agar klien memahami seluk beluk yang dialami secara mendalam dan komprehensif, positif, dan dinamis. Kedua, merujuk kepada fungsi pengentasan, maka layanan konseling individu bertujuan untuk mengentaskan klien dari masalah yang dihadapinya. Ketiga, dilihat dari fungsi pengembangan dan pemeliharaan, tujuan layanan konseling individu adalah untuk mengembangkan potensi-potensi individu dan memlihara unsur-unsur positif yang ada pada diri klien. Dan seterusnya sesuai dengan fungsi-fungsi bimbingan dan konseling di atas.
Adapun Tujuan layanan konseling individu adalah sebagai berikut: 1). Memiliki komitmen yang kuat dalam mengamalkan nilai-nilai keimanan dan ketakwaan kepada Tuhan Yang Maha Esa, baik dalam kehidupan pribadi, keluarga, pergaulan dengan teman sebaya, sekolah, tempat kerja, maupun masyarakat pada umumnya.2). Memiliki sikap toleransi terhadap umat beragama lain saling menghormati dan memelihara hak dan kewajibanya masing-masing. $\quad 3$ ). Memiliki pemahaman tentang irama kehidupan yang bersifat fluktuatif antara yang menyenangkan (anugrah) dan yang tidak menyenangkan (musibah), serta mampu meresponya secara positif sesuai dengan ajaran agama yang dianut. Memiliki pemahamam dan penerimaan diri secara objektif dan konstruktif, baik yang terkait dengan keunggulan maupun kelemahan; baik fisik maupun psikis. 4). Memiliki sikap positif atau respek terhadap diri sendiri dan orang lain. 5). Memiliki kemampuan melakukan pilihan secara sehat. 6). Bersikap respek terhadap orang lain, menghormati atau menghargai orang lain, tidak melecehkan martabat atau harga dirinya.7). Memiliki rasa tanggung jawab yang diwujudkan dalam bentuk komitmen terhadap tugas atau kewajibannya. 8). Memiliki kemampuan berinteraksi sosial, yang diwujudkan dalam bentuk hubungan persahabatan, persaudaraan, atau silaturahim dengan sesama manusia. 9). Memiliki kemampuan dalam menyelesaikan konflik (masalah) baik bersifat internal (dalam diri sendiri) maupun orang lain. 10). Memiliki kemampuan untuk mengambil keputusan secara efektif.

Menurut Prayitno, teknik-teknik konseling yang secara langsung diterapkan terhadap klien, antara lain: a). Konseling Direktif (Directive Conseling). Pendekatan ini dipelopori oleh E.G Williamson dan J.G Darley yang 
berasumsi dasar bahwa klien tidak mampu mengatasi sendiri masalah yang dihadapinya. Karena itu, klien membutuhkan bantuan dari orang lain, yaitu konselor. Klien bersifat menerima perlakuan dan keputusan yang dibuat konselor. Konseling direktif menurut langkah-langkah umum sebagai berikut: 1). Analisis data tentang klien. 2). Pensistesisan data untuk mengenali kekuatan-kekuatan dan kelemahankelemahan klien, 3). Diagnosis masalah. 4). Prognosis atau prediksi tentang perkembangan masalah selanjutnya. 5). Pemecahan masalah. 6). Tindak lanjut dan peninjauan hasil-hasil konseling. b). Konseling Non-direktif (Non-Directive Counseling). Konseling non-direktif sering disebut juga "Clien Centered Therapy". Konseling non-direktif merupakan upaya bantuan pemecahan masalah yang berpuasat pada klien. Klien diberi kesempatan mengemukakan persoalan, perasaan dan pikiranpikirannya secara bebas. Pendekatan ini berasumsi dasar bahwa seseorang yang mempunyai masalah pada dasarnya tetap memiliki potensi dan mampu mengatasi maslahnya sendiri. C). Konseling Eklektif (elective Counseling). Konseling elektif merupakan penggabungan direktif dan konseling non-direktif. Didasari pada kenyataan praktek konseling menunjukkan bahwa tidak semua masalah dapat dientaskan secara baik hanya dengan satu pendekatan atau teori saja. Pendekatan atau teori mana yang cocok digunakan sangat ditentukan oleh beberapa faktor, antara lain: 1). Sifat masalah yang dihadapi. 2). Kemampuan klien dalam memainkan peranan dalam proses konseling. 4). Kemampuan konselor sendiri, baik pengalaman maupun ketrampilan dalam menggunakan masing-masing pendekatan atau teori konseling.

Teknik-teknik di atas diterapkan secara elektrik, dalam arti tidak harus berurutan di mana yang satu mendahului yang lainya, melainkan dipilih dan terpadu mengacu, kepada kebutuhan proses konseling. Melihat kepada teknik penyelenggaraan konseling perorangan terdapat macam-macam teknik konseling individu yang sangat ditentukan oleh permasalahan yang dialami oleh siswa. Teknik konseling individu yang sederhanan melalui proses/ tahap-tahap sebagai berikut: 1). Tahap pembukaan. 2). Tahap penjelasan. 3). Tahap pengubahan tingkah laku. 4). Tahap penilaian/ tindak lanjut.

Ciri orang yang memahami potensi dirinya bisa diukur atau dilihat dalam sikap dan perilakunya sehari-hari dalam kehidupan keluarga, sekolah dan masyarakat. Menurut La Rose (Sugiharso dkk, 2009) menyebutkan bahwa orang yang berpotensi memiliki ciri-ciri: 1). Suka belajar dan mau melihat kekurangan dirinya. 2). Memilki sikap yang luwes. 3). Berani melakukan perubahan secara total untuk perbaikan. 4). Tidak mau menyalahkan orang lain maupun keadaan, 5). Memilki sikap yang tulus bukan kelicikan, 6). Memiliki rasa tanggung jawab. 7). Menerima kritik saran dari luar. 8). Berjiwa optimis dan tidak mudah putus asa Potensi apapun pada diri manusia masing-masing mempunyai fungsi masing-masing dapat tumbuh dan berkembang baik secara sendiri-sendiri maupun bersama- sama baik disengaja maupun secara alami. Sesuai dengan potensi diri yang telah Allah SWT berikan kepada manusia, konsekuensi logisnya adalah manusia harus memanfaatkan dan mengaktualisasikan semaksimal mungkin dalam hidup dan kehidupanya.

$$
\text { Manusia memiliki beragam }
$$
potensi diantaranya adalah sebagai berikut (Nashori, 2003): 1). Potensi Berfikir. Manusia memiliki potensi berfikir. Seringkali Allah menyuruh manusia untuk berfikir. Logikanya orang 
hanya disuruh berfikir karena ia memiliki potensi berfikir. Maka, dapat dikatakan bahwa setiap manusia memiliki potensi untuk belajar informasi-informasi baru, menghubungkan berbagai informasi, serta menghasilkan pemikiran baru. 2). Potensi Emosi. Potensi yang lain adalah potensi dalam bidang afeksi/emosi. Setiap manusia memilki potensi cita rasa, yang dengannya manusia dapat memahami orang lain, memahami suara alam, ingin mencintai dan dicintai, memperhatikan dan diperhatikan, menghargai dan dihargai, cenderung kepada keindahan. 4). Potensi Fisik. Adakalanya manusia memilki potensi yang luar biasa untuk membuat gerakan fisik yang efektif dan efisien serta memiliki kekuatan fisik yang tangguh. Orang yang berbakat dalam bidang fisik mampu mempelajari olah raga dengan cepat dan selalu menunjukkan permainan yang baik. 5). Potensi Sosial. Pemilik potensi sosial yang besar memiliki kapasitas menyesuaikan diri dan mempengaruhi orang lain. Kemampuan menyesuaikan diri dan mempengaruhi orang lain didasari kemampuan belajarnya, baik dalam dataran pengetahuan maupun keterampilan.

\section{METODE PENELITIAN}

Penelitian ini menggunakan metode penentuan subjek, dimana siswa yang menjadi subyek penelitian adalah siswa yang tidak bisa menyesuaikan diri atau memiliki penyesuaian diri yang rendah. Metode pengumpulan data menggunakan metode pemberian angket sebagai metode pokok sedangkan metode observasi, dokumentasi dan interviu atau wawancara digunakan sebagai metode pelengkap. Metode pengumpulan data adalah analisis data yang menggunakan rumus uji wilxocon untuk menguji kebenaran hipotesis. penelitian ini termasuk dalam jenis penelitian eksperimen, dimana dalam penelitian eksperimen ini terdapat dua variabel yaitu variabel bebas dan variabel terikat, dimana konseling individu sebagai variabel bebas dan potensi diri sebagai variabel terikat.

Penelitian ini termasuk penelitian eksperimen, dimana dalam penelitian ini menggunakan desain penelitian OneGroup Pre test-Post test Design. Dalam penelitian ini menggunakan satu sampel yaitu kelompok eksperimen sebagai kelompok yang diberikan perlakuan. Untuk melihat hasil pengaruh variabel $\mathrm{O}_{1}$ terhadap variabel $\mathrm{O}_{2}$ diberikan pre-test dan post-test kepada kelompok tersebut yang dilaksanakan sebelum dan sesudah memberikan perlakuan. Pengaruh perlakuan $\mathrm{O}_{1}$ dapat diketahui dengan membandingkan antara hasil pre test dan post test.

Dalam penelitian ini, data yang akan diperoleh adalah data tentang pengaruh konseling individu Terhadap potensi diri Siswa tunarungu di Sekolah Inklusi. Maka data yang diperoleh adalah data yang bersifat kuantitatif (bergejala interval) yang berupa angka-angka. Kemudian langkah-langkah pelaksanaan metode analisis statistik sebagai cara untuk mengolah data untuk memperoleh hasil yang sesuai dengan yang diinginkan atau diharapkan.

\section{HASIL PENELITIAN DAN PEMBAHASAN}

Dalam Penelitian ini, data yang diperoleh melalui tes dianalisis dengan menggunakan rumus $t$-test, akan tetapi sebelum data-data tersebut dianalisis menggunakan rumus statistik t-test, peneliti terlebih dahulu melakukuan tabulasi atas jawaban yang sudah terkumpul. Angket yang terkumpul diberikan skor sesuai dengan ketentuan dalam bab sebelumnya. Adapun data yang dikumpulkan dari hasil angket sebagaiman pada tabulasi angket (pretest) dan (post-test). 
Analisis t-test dilakukan untuk mengetahui Pengaruh Konseling Individu Terhadap Potensi Diri Anak Tunarungu Di Sekolah Inklusi SMKN 5 Mataram Tahun Pelajaran 2020/2021.dan digunakan untuk menguji hipotesis yang diajukan. Untuk Keperluan perhitungan analisis statistik, maka hipotesis alternatif (Ha) yang yang berbunyi: ada Pengaruh Konseling Individu Terhadap Potensi Diri Anak Tunarungu Di Sekolah Inklusi SMKN 5 Mataram Tahun Pelajaran 2020/2021, maka perlu diubah terlebih dahulu ke dalam hipotesis nol (Ho) sehingga berbunyi: tidak ada Pengaruh Konseling Individu Terhadap Potensi Diri Anak Tunarungu Di Sekolah Inklusi SMKN 5 Mataram Tahun Pelajaran 2020/2021.

Menyusun tabel deviasi Pre-test dan Post-test dimaksudkan untuk mengetahui deviasi yang diperoleh sebelum dan sesudah pemberian Bimbingan Karier. Cara menyusun tabel deviasi Pre-test dan post- test lebih jelasnya dapat dilihat pada tabel di bawah ini

Tabel: Tabel Kerja Untuk Pengujian Hipotesis Pengaruh Konseling Individu Terhadap Potensi Diri Anak Tunarungu Di Sekolah Inklusi

\begin{tabular}{|c|c|c|c|c|c|c|}
\hline No & $\begin{array}{l}\text { Kode } \\
\text { Siswa }\end{array}$ & $\begin{array}{c}\text { Pree- } \\
\text { test }\end{array}$ & $\begin{array}{c}\text { Post- } \\
\text { test }\end{array}$ & $\begin{array}{c}\text { Gaind } \\
\text { (d) } \\
\text { (Post- } \\
\text { Pree })\end{array}$ & $\begin{array}{c}\text { Xd } \\
\text { (d- } \\
\text { Md) }\end{array}$ & $\sum \mathbf{x d}^{2}$ \\
\hline (1) & (2) & (4) & (3) & (5) & (6) & (7) \\
\hline 1 & BHPK & 37 & 40 & 3 & 4.857 & 23.590 \\
\hline 2 & NL & 37 & 42 & 5 & 2.857 & 8.162 \\
\hline 3 & YK & 37 & 43 & 6 & 1.857 & 3.448 \\
\hline 4 & AIM & 37 & 41 & 4 & 3.857 & 14.876 \\
\hline 5 & FADS & 37 & 45 & 8 & 0.143 & 0.020 \\
\hline 6 & APT & 26 & 40 & 14 & 6.143 & 37.736 \\
\hline 7 & HRAW & 24 & 39 & 15 & 7.143 & 51.022 \\
\hline \multicolumn{2}{|c|}{$N=7$} & 290 & 235 & $\begin{array}{c}\mathbf{5 5} \\
\mathbf{M d}= \\
\mathbf{7 , 8 5 7}\end{array}$ & & $\begin{array}{l}\sum X^{2} d= \\
\mathbf{1 3 8 . 8 5 4}\end{array}$ \\
\hline
\end{tabular}

Berdasarkan hasil perhitungan $t$ test yang diperoleh melalui analisis, ternyata nilai $\mathrm{t}$ diperoleh $=4.321$ kemudian dikonsultasikan dengan nilai $\mathrm{t}$ dalam tabel dengan $\mathrm{db}(\mathrm{N}-1)=7-1=6$ dengan taraf signifikansi $5 \%=2.447$. Berdasarkan hasil anaisis data yang diperoleh yaitu: ( $\mathrm{t}$ hitung $4.321>\mathrm{t}$ table 2.447). Sehingga dari landasan teori yang telah diajukan, jika dibandingkan dengan analisis data yang diperoleh melalui penelitian dengan menggunakan analisis statistik dengan rumus $t$-test ternyata hipotesis nol (Ho) yang berbunyi: Tidak Ada Pengaruh Konseling Individu Terhadap Potensi Diri Anak Tunarungu Di Sekolah Inklusi SMKN 5 Mataram Tahun Pelajaran 2020/2021. “ditolak”, dan hipotesis alternatif (Ha) yang berbunyi: Ada Pengaruh Konseling Individu Terhadap Potensi Diri Anak Tunarungu Di Sekolah Inklusi SMKN 5 Mataram Tahun Pelajaran 2020/2021. "diterima".

Pemberian treatment konseling individu dalam bentuk kelompok. Karena dalam penelitian ini menggunakan one group pre-test post-test design. Dengan demikian, bahwa pelaksanaan konseling individu mempunyai peranan yang positif dalam membantu meningkatkan potensi diri Pada Siswa Tunarungu Di Sekolah Inklusi SMKN 5 Mataram Tahun Pelajaran 2020/2021. Awalnya penelliti menetapkan populasi 30 orang siswa, kemudian setelah melakukan pretest ternyata yang mencapai nilai sikap sensitif tinggi berjumlah 7 orang siswa yang diantaranya 4 laki-laki dan 3 perempuan, selanjutnya peneliti melakukan treatmentterhadap 7 orang siswa tersebut, selesai melakukan treatment baru memberikan post test. Hasil dari dari post test menujukkan bahwa tingkat sikap sensitif tersebut menurun. Jadi semua siswa tunarungu memiliki potensi diri yang rendah.

Berdasarkan hasil anaisis data yang diperoleh yaitu: ( $\mathrm{t}$ hitung $4.321>\mathrm{t}$ table 2.447). Sehingga dari landasan teori yang telah diajukan, jika dibandingkan dengan analisis data yang diperoleh melalui penelitian dengan menggunakan analisis 
statistik dengan rumus t-test ternyata hipotesis nol (Ho) yang berbunyi: Tidak Ada Pengaruh Konseling Individu Terhadap Potensi Diri Anak Tunarungu Di Sekolah Inklusi SMKN 5 Mataram Tahun Pelajaran 2020/2021. “ditolak", dan hipotesis alternatif (Ha) yang berbunyi: Ada Pengaruh Konseling Individu Terhadap Potensi Diri Anak Tunarungu Di Sekolah Inklusi SMKN 5 Mataram Tahun Pelajaran 2020/2021. "diterima". Dengan demikian, semakin baik penerapan konseling Individu Terhadap Potensi Diri Anak Tunarungu Di Sekolah Inklusi SMKN 5 Mataram Tahun Pelajaran 2020/2021. menjadi semakin meningkat.

\section{SIMPULAN DAN SARAN}

Berdasarkan hasil analisis data dapat dilihat dari hasil penelitian yaitu: ( $t$ hitung4.321> $\mathrm{t}$ tabel2.447) maka hipotesis nihil (Ho) ditolak sedangkan hipotesis alternatif (Ha) diterima pada tarafsignifikansi 5\% maka dapat di simpulkan bahwa: Ada menunjukkan ( $\mathrm{t}$ hitung $4.321>\mathrm{t}$ table 2.447), sehingga penelitian ini dinyatakan "Signifikan".

Berdasarkan simpulan di atas, peneliti dapat memberi saran kepada semua pihak yang terkait, adapun saransarannya sebagai berikut: Kepala Sekolah, supaya mendukung pentingnya pelaksanaan konseling individu disekolah guna meningkatkan potensi diri siswa tunarungu menjadi lebih baik, untuk menunjang pelaksanaan kegiatan layanan yang diberikan kepada siswa serta memahami pentingnya pemberian layanan BK disekolah. Kepada Guru BK, supaya memberikan program layanan konseling individu untuk meningkatkan potensi diri siswa menjadi lebih baik. Guru Bidang Studi untuk ikut mendukung pemberian layanan konseling individu guna meningkatkan ptensi diri siswa tunarungu. Bagi Orang Tua/Wali, supaya ikut mendukung pemberian layanan dan menganjurkan anak mengikuti kegiatan pemberian layanan konseling individu sehingga potensi diri siswa dapat di gali dan ditingkatkan. Kepada siswa kelas X dan XI, supaya mengikuti kegiatan konseling individu untuk dapat mendalami dan meningkatkan potensi diri yang mereka miliki. Kepada peneliti lain, diharapkan kepada peneliti lain yang berminat meneliti kembali tentang masalah ini, agar mengadakan penelitian yang lebih mendalam dan lebih luas khususnya mengenai aspek-aspek yang belum terungkap dalam penelitian ini.

\section{DAFTAR PUSTAKA}

Ahmadi, Abu. (2007). Psikologi Sosial. Rineka Cipta, Jakarta

Ali, Mohammad dan Asrori, Mohammad. (2010). Psikologi Remaja Perkembangan Peserta Didik. Jakarta: Bumi Aksara.

Arikunto, S. (2006). Metode Penelitian Kualitatif. Jakarta: Bumi Aksara.

Cholid Narbuko dan H. Abu Achmad. (2007). Metodologi Penelitian. Jakarta: Bumi Aksara.

Efendi, Mohammad. (2006). Pengantar Psikopedagogik Anak Berkelainan. Jakarta: PT. Bumi Aksara.

Endra K. Prihadhi, (2004). My Potensi. Jakarta: Elek Media Komputindo.

Gerald Corey, (2009). Teori dan Praktek Konseling dan Psikoterapi. Bandung: Refika Aditama.

Hadi, Sutrisno. (2004). Metodologi Research. Yogyakarta: Andi Offset.

Hariadi Ahmad dan Aluh Hartati. 2016. Panduan Pelatihan Self Advocacy Siswa SMP untuk Konselor Sekolah. LPP Mandala. Mataram

Hariadi Ahmad dan Aluh Hartati. 2016.

Penerapan Teknik Structure Learning Approach dalam Meningkatkan Self Advocacy 
https://e-journal.undikma.ac.id/index.php/realita

Mahasiswa Prodi BK IKIP Mataram. Realita Jurnal Bimbingan dan Konseling Vol. 1 No 2 Edisi Oktober 2016. Hal 117 - 127. Prodi Bimbingan dan Konseling Fakultas Ilmu Pendidikan IKIP Mataram

Hariadi Ahmad dan Dini Kurnia. 2017.

Pengaruh Teknik Biblio Edukasi Terhadap Rasa Rendah Diri Pada Siswa Kelas XI di SMA Negeri 8 Mataram. Realita Jurnal Bimbingan dan Konseling Vol. 2 No 1 Edisi April 2017. Hal 194 202. Prodi Bimbingan dan Konseling Fakultas Ilmu Pendidikan IKIP Mataram

Hariadi Ahmad, dan Yolana Oktaviani. 2019. Pengaruh Teknik Self Instruction Terhadap Harga Diri Siswa Kelas Kelas XI di SMK Negeri 1 Lingsar Kabupaten Lombok Barat. Realita Jurnal Bimbingan dan Konseling Vol. 4 No 2 Edisi Oktober 2019. Hal 806 - 815. Prodi Bimbingan dan Konseling Fakultas Ilmu Pendidikan IKIP Mataram.

Hasrul dan Hariadi Ahmad. 2021. Mereduksi Prasangka Etnik Siswa dengan Teknik Restructuing Cognitive Suatu Krangka Konseptual. Realita Jurnal Bimbingan dan Konseling Vol. 6 No 1 Edisi April 2021. Hal 1213 - 1222. Prodi Bimbingan dan Konseling Fakultas Ilmu Pendidikan dan Psikologi Universitas Pendidikan Mandalika.

Ilahi, Muhammad Takdir. (2013). Pendidikan Inklusif. Jogjakarta: Ar-Ruzz Media.

Majdi, Udo Yamin Efendi. (2007). Quranic Quotient. Jakarta: Qultum Media

Mardalis, (2009). Metode Penelitian. Bumi Aksara: Jakarta.
Margono, S. (2005). Metodologi Penelitian Pendidikan. Jakarta: PT. Rineka Cipta.

Mudjito, dkk (2012). Pendidikan Inklusif. Jakarta: Baduose Media.

Prayitno dan Erman Amti, (2004). DasarDasar Bimbingan Konseling. Jakarta: PT Asdi Mahasatya.

Sofyan S. Willis, (2014). Konseling Individual Teori dan Praktek, Bandung: Alfabeta,

Sri Habsari, (2005). Bimbingan \& Konseling SMA kelas XI. Jakarta: Grasindo.

Sugiharso, dkk (2009). Pendidikan Kewarganegaraan. Jakarta: Pusat Perbukuan Departemen Pendidikan Nasional.

Sugiyono, (2010). Metode Penelitian Pendidikan Pendekatan Kuantitatif, Kualitatif, dan R\&D. Bandung: Alfabeta. 


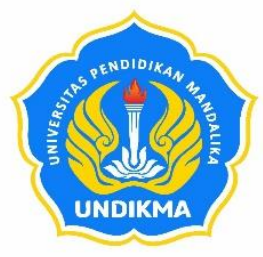

\section{UNIVERSITAS PENDIDIKAN MANDALIKA FAKULTAS ILMU PENDIDIKAN DAN PSIKOLOGI PROGRAM STUDI BIMBINGAN DAN KONSELING Jurnal Realita}

Gedung Dwitiya Lt.3. Jln Pemuda 59A Mataram-NTB 83125 Tlp (0370) 638991 e-mail: realita@undikma.ac.id; web: e-journal.undikma.ac.id

\section{PEDOMAN PENULISAN}

1. Naskah merupakan hasil penelitian, pengembangan atau kajian kepustakaan di bidang pendidikan, pengajaran, pembelajaran, bimbingan dan konseling, dan Psikologi

2. Naskah merupakan tulisan asli penulis dan belum pernah dipublikasikan sebelumnya dalam jurnal ilmiah lain,

3. Naskah dapat ditulis dalam Bahasa Indonesia atau Bahasa Inggris.

4. Penulisan naskah mengikuti ketentuan sebagai berikut:

$\begin{array}{llll}\text { Program } & \text { MS Word } & \text { Margin kiri } & 3.17 \mathrm{~cm} \\ \text { Font } & \text { Times New Roman } & \text { Margin kanan } & 3.17 \mathrm{~cm} \\ \text { Size } & 12 & \text { Margin atas } & 2.54 \mathrm{~cm} \\ \text { Spasi } & 1.0 & \text { Margin bawah } & 2.54 \mathrm{~cm} \\ \text { Ukuran kertas } & \text { A4 } & \text { Maksimum 20 halaman }\end{array}$

5. Naskah ditulis dengan sistematika sebagai berikut: Judul (huruf biasa dan dicetak tebal), nama-nama penulis (tanpa gelar akademis), instansi penulis (program studi, jurusan, universitas), email dan nomor telpon penulis, abstrak, kata kunci, pendahuluan (tanpa sub-judul), metode penelitian (tanpa sub-judul), hasil dan pembahasan, simpulan dan saran (tanpa sub-judul), dan daftar pustaka.

Judul secara ringkas dan jelas menggambarkan isi tulisan dan ditulis dalam huruf kapital. Keterangan tulisan berupa hasil penelitian dari sumber dana tertentu dapat dibuat dalam bentuk catatan kaki. Fotocopy halaman pengesahan laporan penelitian tersebut harus dilampirkan pada draf artikel.

Nama-nama penulis ditulis lengkap tanpa gelar akademis.

Alamat instansi penulis ditulis lengkap berupa nama sekolah atau program studi, nama jurusan dan nama perguruan tinggi. Penulis yang tidak berafiliasi pada sekolah atau perguruan tinggi dapat menyertakan alamat surat elektronik dan nomor telpon.

Abstrak ditulis dalam 2 (dua) bahasa: Bahasa Inggris dan Bahasa Indonesia. Naskah berbahasa Inggris didahului abstrak berbahasa Indonesia. Naskah berbahasa Indonesia didahului abstrak berbahasa Inggris. Panjang abstrak tidak lebih dari 200 kata. Jika diperlukan, tim redaksi dapat menyediakan bantuan penerjemahan abstrak kedalam bahasa Inggris.

Kata kunci (key words) dalam bahasa yang sesuai dengan bahasa yang dipergunakan dalam naskah tulisan dan berisi 3-5 kata yang benar-benar dipergunakan dalam naskah tulisan.

Daftar Pustaka ditulis dengan berpedoman pada Pedoman Penulisan Karya Ilmiah Universitas Pendidikan Mandalika. 


\begin{tabular}{|c|c|c|c|c|c|}
\hline & & & & \\
JURNAL & VOLUME & NOMOR & EDISI & HALAMAN & P ISSN : 2503 - 1708 \\
REALITA & 6 & 2 & Oktober 2021 & $1326-1430$ & E ISSN : 2722 - 7340 \\
& & & & \\
\hline
\end{tabular}

Alamat Qedaksi:

Program Studi Bimbingan dan Konseling Fakultas Ilmu Pendidikan dan Psikologi

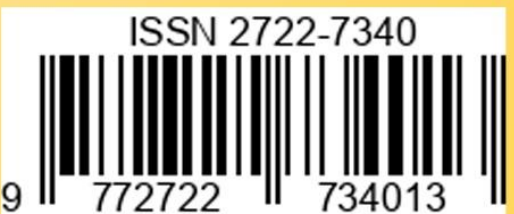

Universitas Pendidikan Mandalika

Gedung Dwitiya, Lt. 3 Jalan Pemuda No. 59A Mataram Telp. (0370) 638991

Email : realita@undikma.ac.id

Web : e-journal.undikma.ac.id

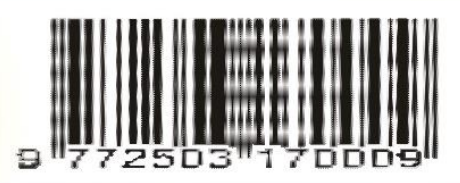

